\title{
PROFESIONALISME DOSEN LUAR BIASA (DLB) PADA ERA MILENIAL DI UIN SUNAN AMPEL SURABAYA: SEBUAH STUDI ANALISIS KONTEN
}

\author{
Ana Toni Roby Candra Yudha \\ Universitas Islam Negeri Sunan Ampel Surabaya \\ anatoniroby@uinsby.ac.id
}

\begin{abstract}
Abstrak
Dosen luar biasa (DLB) adalah dosen yang ritme kerjanya selalu menyesuaikan jam mengajar. Kinerja DLB tidak kalah penting kontributif dan efektif dengan dosen tetap lainnya dalam melakukan pekerjaannya, tentunya pekerjaan yang berkenaan dengan Tri Dharma Perguruan Tinggi. Apabila kinerja dalam komponen Tri Dharma Perguruan Tinggi dapat konsisten dan produktif, maka hal tersebut akan nampak pada sikap profesionalismenya. Tujuan studi ini adalah untuk mengetahui profesionalisme DLB dengan menyelidiki unsur pemenuhan unsur- unsur profesionalisme DLB yang mengabdi di UIN Sunan Ampel Surabaya. Pendekatan penelitian menggunakan pendekatan kualitatif, dan analisis konten. Sumber dan jenis data menggunakan data primer, sedangkan informan adalah DLB itu sendiri dan metode triangulasi sebagai metode yang perlu dilakukan selain wawancara mendalam guna mendapatkan data yang obyektif, akurat dan transparan.

Hasil penelitian ini adalah profesionalisme dapat dilihat setidaknya dari lima kategori, yaitu kepemimpinan institusi, kompensasi finansial dan non finansial, komitmen pada institusi, etos kerja dan hasil kerja. Berdasarkan hasil wawancara dengan informan diperoleh hasil bahwa DLB memiliki penilaian cukup baik terhadap seluruh kategori yang ditanyakan, namun tidak sedikit pula mereka masih berharap atas perbaikan di sejumlah elemen sistem pengajaran seperti sarana, metode evaluasi belajar, pembayaran hak dan apresiasi atas kinerja DLB . Sedangkan saran yang bersesuaian dengan objek hasil studi tersebut adalah lebih banyak diperuntukkan bagi institusi, mengingat melihat kerja dan etos kerja DLB sudah maksimal seperti datang mengajar ontime, memberikan bahan ajar sesuai dokumen kurikulum, dan hal relevan lainnya. Saran untuk institusi lebih mengerucut pada dua hal yaitu perbaiki sarana pengajaran, serta tepatkan waktu saat pemberian hak pada DLB.
\end{abstract}

\section{Kata Kunci: profesionalisme, dosen luar biasa (DLB), era milenial}

\section{PERMASALAHAN}

Era milenial adalah era atau masa yang identik dengan digitalisasi, maka pada era yang disebut era milenial ini berimplikasi kepada seluruh elemen kehidupan. Ide kreatif, etos kerja yang semakin baik serta keunggulan kompetitif merupakan wujud peningkatan level profesional kerja di berbagai level bidang. Atas dasar itulah maka, seorang pendidik baik itu adalah seorang guru (pengajar di level sekolah) maupun seorang dosen (pengajar di level perguruan tinggi) harus menjawab tantangan untuk menujukkan kinerja profesionalnya yang akhirnya dapat memberikan kualitas pendidikan terbaik bagi mahasiswanya.

Dosen luar biasa (DLB) adalah dosen atau pengajar yang sistem kerjanya adalah paruh waktu. Profil seorang DLB identik dengan kefleksibelitasan kerja, karena mereka tidak harus incharge setiap hari di kantor sebagaimana yang dilakukan oleh sebagian besar pegawai tetap pada umunnya. Adanya hal tersebut maka, seorang DLB dapat beraktivitas dimanapun dan kapanpun. DLB merupakan merupakan salah satu komponen tenaga kependidikan yang penting.

Karena tenaga kependidikan adalah pihak yang menyelenggarakan pendidikan yang meliputi aspek mengajar, mengabdi, meneliti serta mengembangkan dan memberikan layanan teknis 
dalam pendidikan. Nilai-nilai tersebut itulah yang kemudian dapat dituangkan dalam rumusan yang disebut denngan profesionalisme.

Kategori yang kemudian dituangkan pada konsep profesionalisme berturut-turut dijelaskan oleh penilaian pengetahuan, keterampilan, dan ketaatan kode etik. Adapun perspektif lain dalam mengukur sebuah profesionalisme dengan menggunakan beberapa ukuran indikator yang identik dengan pendekatan kuantitatif yaitu dengan menilai kualitas kerja, kuantitas kerja, kendalan, dan sikap. Alur kinerja profesionalisme yang terdapat dalam dunia birokrasi dan Kinerja Pegawai dalam sebuah institusi dapat diamati sebagaimana dijelaskan pada gambar bagan alur berikut ini.

\begin{tabular}{|c|c|c|}
\hline $\begin{array}{l}\text { Aspek-aspek Profesionalisme } \\
\text { Birokrasi (Martin dan } \\
\text { Schinzinger terjemahan Widodo, } \\
\text { 1994:192) }\end{array}$ & $\begin{array}{l}\text { Hubungan yang } \\
\text { dapat dijalin } \\
\text { antara }\end{array}$ & $\begin{array}{c}\text { Faktor-faktor } \\
\text { Kinerja Pegawai } \\
\text { (Mangkunegara, 2004: 15) }\end{array}$ \\
\hline $\begin{array}{l}\text { Meliputi: } \\
\text { i. } \text { Pengetahuan } \\
\text { ii. } \text { Keterampilan } \\
\text { iii. Ketaatan Kode Etik }\end{array}$ & $\begin{array}{l}\text { Birokrasi } \\
\text { dengan Kinerja } \\
\text { Pegawai } \\
\text { (Harits, 2006; } \\
\text { 15) }\end{array}$ & \begin{aligned} & \multicolumn{2}{l}{ Meliputi: } \\
& i. Kualitas Kerja \\
& ii. Kuantitas Kerja \\
& iii. Keandalan \\
& iv. Sikap \end{aligned} \\
\hline
\end{tabular}

\section{Gambar 1:. Aspek Profesionalisme di lembaga Birokrasi}

Berdasarkan gambar 1 mengenai aspek profesionalisme di lembaga birokrasi dan pola kerja pegawai diulas bahwa, aspek profesional yang meliputi pengetahuan, keterampilan dan ketaatan kode etik, yang kemudian berhubungan dengan faktor-faktor kinerja pegawai atau dosen yang meliputi kualitas kerja, kuantitas kerja, sikap keandalah dan sikap keseharian. Apabila nilai-nilai dan pola hubungan tersebut di atas dapat dikerjakan, maka tingkat profesionalisme akan mendekati level sempurna.

Mengingat tugas dan kapasitas seorang dosen sebagai pendidik, pengabdi dan peneliti di perguruan tinggi manapun dan di level manapun yang khususnya di lingkup civitas akademika UIN Sunan Ampel Surabaya, serta tidak kalah penting pula tugasnya dalam memberikan edukasi softskill atau keterampilan dan perilaku santun serta kemampuan akademis yang cemerlang bagi para mahasiswan/i khususnya serta komunitas disekitarnya pada umumnya. Maka menarik untuk dilakukan proses pengkajian dan penelitian dengan terjun secara langsung di lapangan yang tujuannya adalah untuk mengetahui seberapa besar ukuran kinerja profesionalisme sehingga dapat disusun usulan saran rekomendasi yang membangun, dalam rangka untuk meningkatkan kinerja mereka di lingkungan kampus UIN Sunan Ampel Surabaya secara khusus, dan di seluruh perguruan tinggi lainnya tempatya mengabdi.

\section{Rumusan Masalah}

Bersesuaian dengan latar belakang, maka masalah penelitian ini dapat dirumuskan menjadi pertanyaan: 
a. Bagaimana profesionalisme DLB di lingkungan UIN Sunan Ampel Surabaya di Surabaya?

b. Bagaimana implementasi prefesionalisme DLB UIN Sunan Ampel kepada civitas akademika UIN Sunan Ampel Surabaya di sekitarnya?

\section{METODE PENELITIAN}

Pendekatan penelitian yang digunakan akan memperhatikan latar belakag, rumusan masalah dan tujuan penelitian, maka pendekatan penelitian yang dipakai adalah pendekatan penelitian kualitatif. Penelitian dengan pendekatan kualitatif dinilai sesuai pada penelitian yang memiliki subjek penelitian seperti motivasi, persepsi, dan perilaku. Berkenaan dengan studi ini yang menelaah dan mengamati tingkat profesionalisme, maka hal ini dapat dikategorikan sebagai pendekatan penelitian yang berbasis pada perilaku dan persepsi.

Pada studi ini peneliti akan secara langsung berinteraksi dengan Dosen Luar Biasa (DLB) dalam melakuka wawancara, penilaian dan observasi guna mendapatkan gambaran dan wawasan yang jauh lebih komprehensif. Komprehensif di sini bermakna bahwa ulasan dan uraian yang diperoleh dari DLB dan pimpinan pada level Dekanat, akan memberikan gambaran fungsi control dalam menjaga ritme dan kontinuitas profesionalisme kinerja.

Data yang digunakan pada penelitian ini didominasi oleh data primer, namun juga dilengkapi oleh data sekunder. Data primer penelitian diperoleh dari hasil wawancara dan angket kuesioner yang disebar dan diisi oleh para informan. Informan penelitian merupakan dosen luar biasa (DLB) yang berasal dari beberapa fakultas dan homebase program studi di seluruh lingkup UIN Sunan Ampel Surabaya. Informan yang terpilih menjadi informan penelitian adalah informan yang memiliki reputasi mengajar baik baru beberapa tahun dan masih menjadi DLB atau existing DLB maupun yang sudah lama menjadi DLB namun saat dilakukannya penelitian ini, mereka sudah berubah status menjadi Calon Pegawai Negeri Sipil (CPNS). Berikut adalah sebaran data informan penelitian.

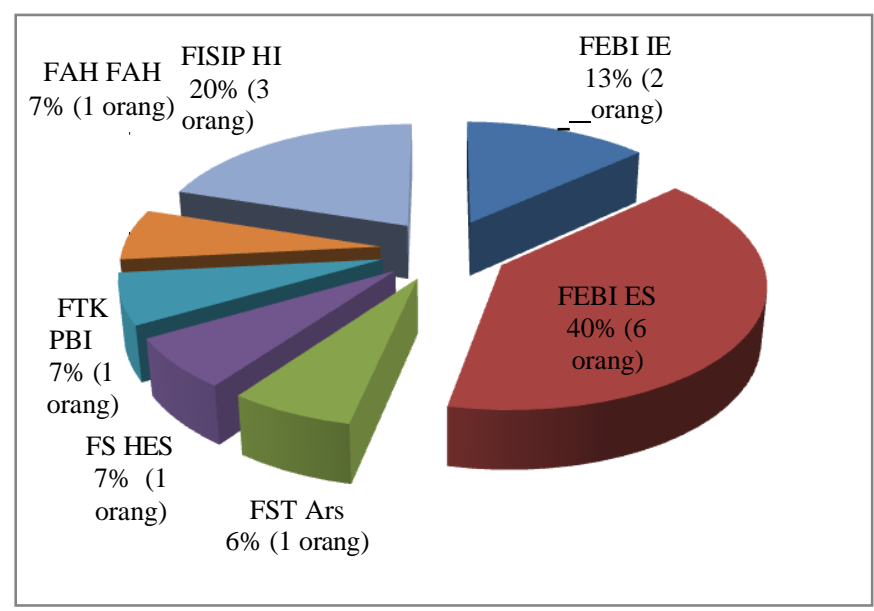

Gambar 2. Sebaran Informan Penelitian

\section{HASIL PENELITIAN}


Hasil penelitian ini akan dipaparkan menjadi dua gambaran besar, yaitu penilaian kinerja profesionalisme dosen luar biasa (DLB) dalam sudut pandang institusi sedangkan yang kedua adalah pemaparan hasil eveluasi profesionalisme lembaga dalam sudut pandang DLB. Menggunakan pendekatan kualitatif, tim penyusun menggunakan setidaknya ada lima dimensi penilaian mulai dari kepemimpinan institusi yang dinilai dari tujuh penilaian penilaian, kompensasi finansial yang dinilai dari enam penilaian penilaian, kemudian ada komitmen pada institusi yang dinilai melalui enam penilaian penilaian, etos kerja yang dinilai dari tujuh penilaian, dan terakhir adalan penilaian melalui kinerja atau prestasi kerja yang dinilai dengan menggunakan tujuh penilaian. Selain pendekatan penelitian adapula pendekatan lain yang digunakan yaitu pendekatan kuantitatif deskriptif yang juga menggunakan lima penilaian penilaian. Lima kategori tersebut adalah penyerahan hak DLB, kebijakan corporate governance yang dalam hal ini direpresentasikan oleh kebijakan institusi melalui fakultas yang terdapat di seluruh elemen sivitas akademika UIN Sunan Ampel Surabaya, praktek corporate governance, penyingkapan atau transparansi, serta kategori terakhir adalah audit.

Perlu diketahui dan dipahami bahwa pendekatan penelitian ini bertujuan untuk penyederhanaan sebuah gambaran atau menggeneralisasi sebuah gambaran umum berupa profesionalisme. Namun, penelitian ini berupaya untuk menggali informasi yang sedalam-dalamnya dari para informan, dengan mencurahkan isi hati, wawasan dan pengalamannya saat bertugas menjadi DLB di lingkup wilayah UIN Sunan Ampel Surabaya, adapun tujuan dari metode ini untuk mendapatkan informasi yang sedail mungkin, bukan untuk menjelaskan gambaran secara umum lagi namun gambaran yang memiliki makna yang dalam. Karena upaya penggalian data pada penelitian ini tidak menggunakan metode batas minimal jumlah data, sebagaimana yang biasa digunakan dalam metode kuantitatif baik dengan menggunakan rumus Slovin, penentuan data minimal sebanya 30 data, dan metode lainnya yang relevan.

Profesionalisme institusi secara representasi tidak mutlak, dapat diamati dari penilaian beberapa dosen DLB yang terdistribusi ke seluruh elemen UIN Sunan Ampel Surabaya yang diwakili oleh 15 orang DLB yang bertugas di enam fakultas. Berikut summary mengenai profesionalisme Dosen Luar Biasa di UIN Sunan Ampel Surabaya dirupakan menjadi pentagram berikut ini. 


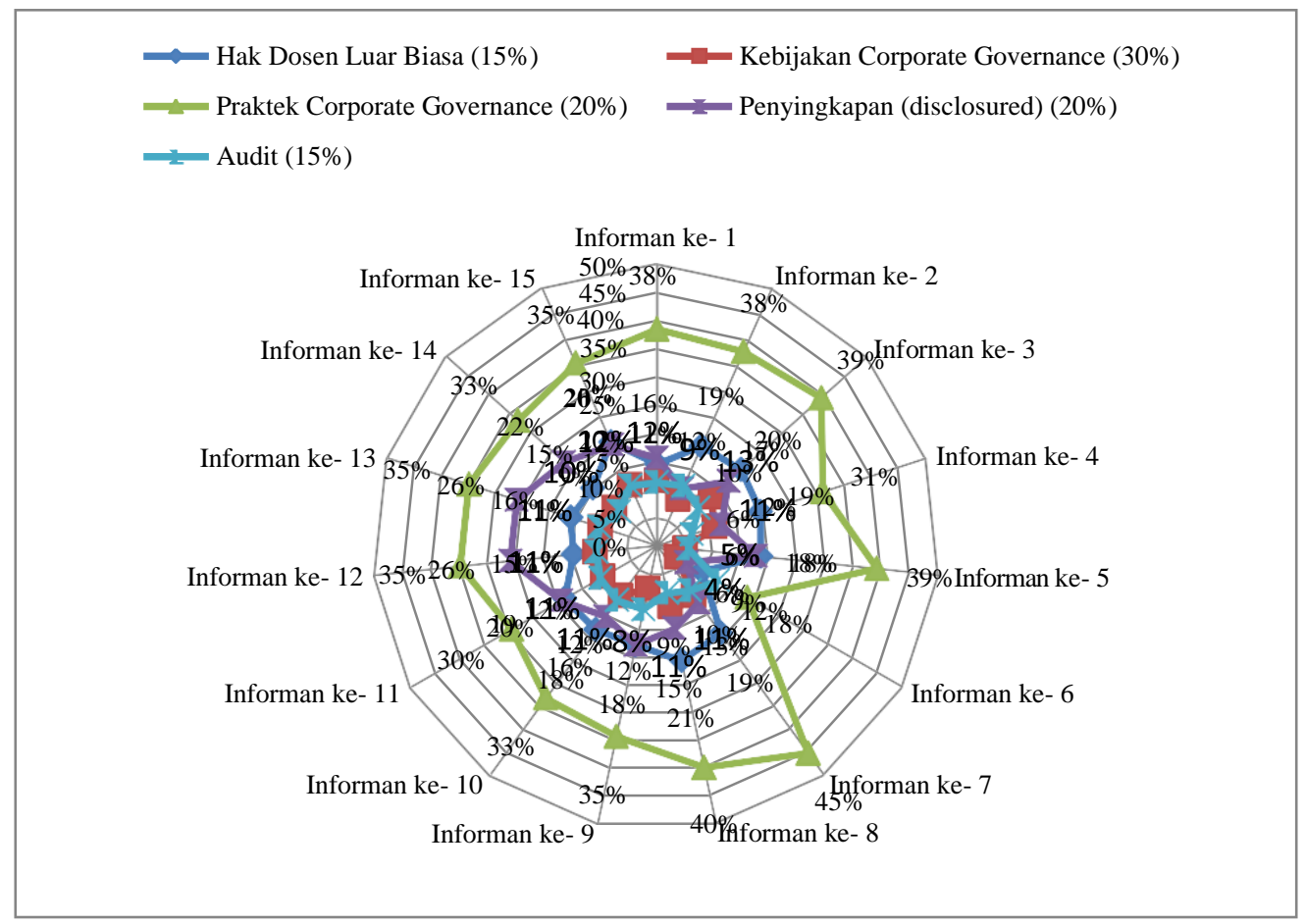

\section{Gambar 3. Summary Profesionalisme DLB di UIN SA Surabaya}

Bersesuaian dengan gambar 3 dapat diamati bahwa ada terdapat 15 DLB yang menjadi asisten penelitian sekaligus informan penelitian. Mereka menilai profesionalisme dari institusi atas kinerja mereka, 14 dari 15 informan yang diwawancarai kemudian dituangkan menjadi pentagram mengemukakan bahwa kepuasan dan keprofesionalismean institusi masih berada di atas 75 persen, sedangkan satu DLB sisanya menyatakan kepuasan dan profesionalisme institusi berada pada nilai 50 persen.

Hal ini memang belum dapat dikatakan representasi dari keseluruhan secara detlil. Namun hasil ini penting untuk digunakan oleh institusi sebagai bahan evaluasi sistem pengajaran, penelitian dan pengabdian masyarakat khususnya yang berkaitan dengan pihak Dosen Luar Biasa (DLB). Sekaligus menjadi dasar rekomendasi dalam penyusunan kebijakan periode selanjutnya menuju perbaikan sistem yang semakin baik dan membaik.

Dari sejumlah Dosen Luar Biasa yang ada di UIN Sunan Ampel Surabaya, sebagian besar DLB merasa belum melakukan pengabdian dan pengajaran yang dilakukan secara optimal. Hanya sepertiga dari keseluruhan data yang didapatkan dari informan DLB yang merasa pengabdian dan pengajaran yang dilakukan sudah optimal.

Terdapat hal-hal yang menjadi kendala terkait dengan pengabdian dan pengajaran yang dilakukan DLB yang belum optimal, baik kendala yang berasal dari fasilitas di kelas yang kurang mendukung maupun fasilitas pembelajaran yang tidak lengkap, serta kendala lain yang berasal dari DLB itu sendiri yaitu kurangnya pengetahuan lapangan tentang materi yang diajarkan, sehingga membuat pengajaran yang diberikan kepada mahasiswa/i dirasa masih belum cukup optimal.

Dikarenakan kendala-kendala tersebut, DLB melakukan sikap yaitu dengan memberikan pengajaran lebih maksimal dengan mencoba untuk memberi waktu pengajaran semaksimal mungkin. DLB berpendapat bahwa optimalisasi dalam melakukan pengabdian dan pengajaran 
dapat ditingkatkan dengan cara adanya infrastruktur yang dapat menunjang proses belajar mengajar, seperti proyektor dan lain-lain.

Hasil yang cukup konsisten didapat dalam studi kali ini yaitu, penilaian komitmen, pemberian penghargaan institusi kepada DLB dalam bentuk finansial maupun non finansial, rasa empati pimpinan terhadap keluhan dan masalah yang dihadapi oleh DLB, juga dilibatkannya para DLB dalam melakukan kegiatan riset dan pengabdian masyarakat, menjadi komponen kategori para DLB dalam menilai kinerja, etos kerja, komitmen dan sikap profesionalisme institusi terhadap mereka. Atau dengan bahasa lain profesionalisme lembaga dalam pandangan DLB khususnya, sudah mendapatkan penilaian yang sudah baik, namun tentunya meskipun mendapatkan penilaian yang cukup baik dari DLB, hal tersebut sudah sepatutnya menjadi bahan masukan dan koreksi atas kinerja institusi untuk terus melakukan improvisasi demi keberlanjutan sistematika kerja yang semakin menguntungkan dan produktif ke depan.

Informan sebanyak 15 orang yang tersebar dan mengajar di seluruh program studi dan fakultas di seluruh unit kerja UIN Sunan Ampel Surabaya. Pola sebaran informan terdiri dari Fakultas Ekonomi dan Bisnis Islam, Fakultas Ilmu Sosial dan Ilmu Politik, Fakultas Sains dan Teknologi, Fakultas Syariah dan Hukum, Fakultas Adab da Humaniora, Fakultas Tarbiyaah dan Keguruan dan Fakultas Dakwah dan Komunikasi. Mereka dinilai komitmen dan profesionalismenya setidaknya menggunakan beberapa kategori, seperti penyaluran atau pemberian hak DLB, komitmen good corporate governance, praktek corporate governance, penyingkapan atau keterbukaan serta audit atau penilaian transparansi.

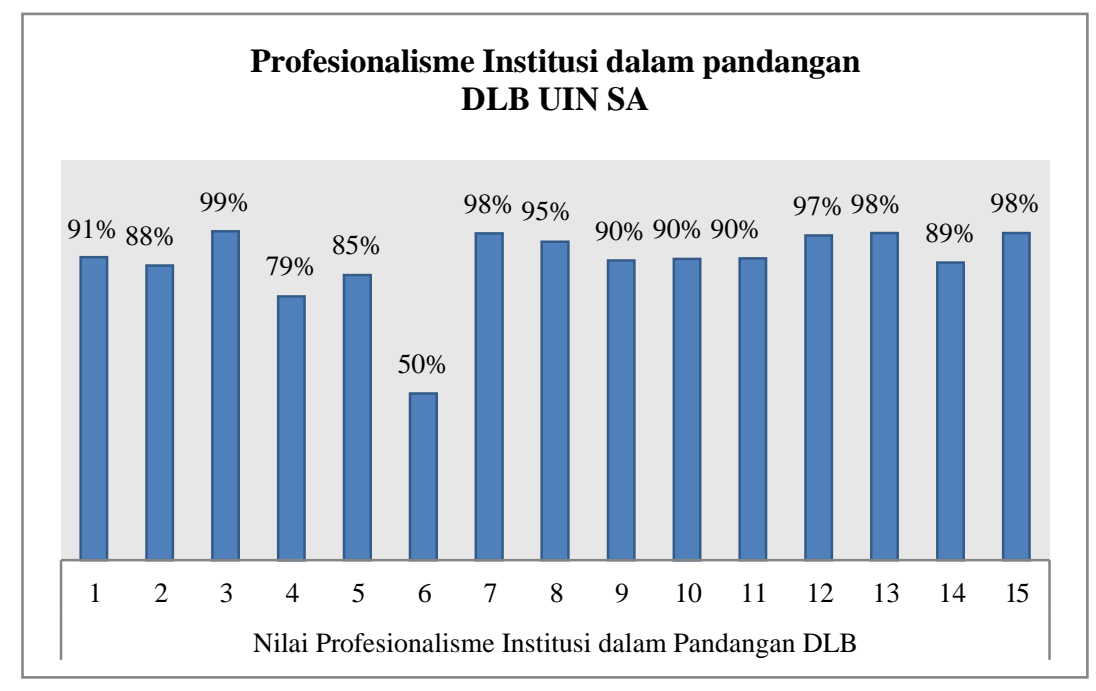

Gambar 4. Profesionalisme Institusi dalam Penilaian Dosen LB

Hal yang dapat dinilai dan dimaknai sebagaimana ulasan data pada gambar 4 bahwa dalam pandangan institusi dapat diamati jika seluruh kinerja yang ditampilkan oleh DLB di masingmasing unit kerja mereka sudah memuaskan, atau dapat dikateogorikan sangat memuakan. Semua penilaian tersebut diperoleh dari hasil wawancara atas opini dan curahan hati para DLB yang dilakukan secara wawancara personal juga dengan metode lain, yaitu dengan menggunakan teknik focus group discussion (FGD).

Namun dalam konteks lain, peneliti juga meminta para DLB untuk memberi penilaian mereka terhadap profesionalisme lembaga atas kinerja yang telah mereka tunjukkan. Hasil yang cukup 
konsisten didapat dalam studi kali ini yaitu, penilaian komitmen, pemberian penghargaan institusi kepada DLB dalam bentuk finansial maupun non finansial, rasa empati pimpinan terhadap keluhan dan masalah yang dihadapi oleh DLB, juga dilibatkannya para DLB dalam melakukan kegiatan riset dan pengabdian masyarakat, menjadi komponen kategori para DLB dalam menilai kinerja, etos kerja, komitmen dan sikap profesionalisme institusi terhadap mereka. Atau dengan bahasa lain profesionalisme lembaga dalam pandangan DLB khususnya, sudah mendapatkan penilaian yang sudah baik, namun tentunya meskipun mendapatkan penilaian yang cukup baik dari DLB, hal tersebut sudah sepatutnya menjadi bahan masukan dan koreksi atas kinerja institusi untuk terus melakukan improvisasi demi keberlanjutan sistematika kerja yang semakin menguntungkan dan produktif ke depan.

\section{ANALISIS DAN PEMBAHASAN}

Bersesuaian dengan latar belakang, rumusan masalah, tujuan penelitian, metode penelitian dan hasil penelitian maka disusunlah bagian analisis dan pembahasan. Pembahasan ini diisi oleh hasil penelitian yang kemudian juga dielaborasi dengan sejumlah teori serta temuan data di lapangan. Profesionalisme Dosen Luar Biasa (DLB) dalam penilaian institusi sebagaimana ulasan yang dibahas pada bagian sebelumnya mengenai motivasi ketepatan hadir. Hampir semua Dosen Luar Biasa (DLB) mengutarakan hal yang sama terkait dengan motivasi datang tepat waktu saat mengajar adalah agar mahasiswa bisa memperoleh pelajaran dan ajaran yang baik dengan berupaya memberikan contoh teladan yang baik sebagai pendidik untuk melatih disiplin, yang selanjutnya diharapkan mahasiswa yang dididik bisa meniru dengan mencontohkannya terlebih dahulu.

Sedangkan terkait dengan mendapat hak, DLB merasa bahwa tidak terdapat transparansi pemberitahuan terkait hak-hak sebagai DLB, sehingga mereka tidak mengetahui hak-hak DLB. Setelah tanggung jawab sudah diselesaikan, seringkali hak DLB (gaji) belum diserahkan atau dipenuhi. Disebabkan karena kontrak kerja yang kurang jelas maka tidak ada hal yang dapat dilakukan bila tanggung jawab sebagai DLB telah dilaksanakan, tetapi hak tidak diberikan. Dalam hal ini, DLB tetap melakukan kewajiban selanjutnya, disertai monitoring atas hak.

Hasil yang cukup konsisten didapat dalam studi kali ini yaitu, penilaian komitmen, pemberian penghargaan institusi kepada DLB dalam bentuk finansial maupun non finansial, rasa empati pimpinan terhadap keluhan dan masalah yang dihadapi oleh DLB, juga dilibatkannya para DLB dalam melakukan kegiatan riset dan pengabdian masyarakat, menjadi komponen kategori para DLB dalam menilai kinerja, etos kerja, komitmen dan sikap profesionalisme institusi terhadap mereka. Atau dengan bahasa lain profesionalisme lembaga dalam pandangan DLB khususnya, sudah mendapatkan penilaian yang sudah baik, namun tentunya meskipun mendapatkan penilaian yang cukup baik dari DLB, hal tersebut sudah sepatutnya menjadi bahan masukan dan koreksi atas kinerja institusi untuk terus melakukan improvisasi demi keberlanjutan sistematika kerja yang semakin menguntungkan dan produktif ke depan. Hasil tersebut dapat diklasifikasikan menjadi beberapa penilaian.

Penilaian pertama yaitu DLB merasa dekat dengan instansi secara emosional. Pada dasarnya, penilaian ini menjelaskan bahwa DLB dalam dirinya memiliki naluri yang kuat dengan keadaan instansi. Penilaian kedua yaitu DLB merasa bangga dalam bekerja dan mengabdi di tempat kampus bekerja. Dalam penilaian ini, DLB yang merupakan alumni dari instansi tersebut meraskan kenyamanan sehingga mereka dapat bekerja dan memberikan kontribusi yang bagus. 
Dalam diri DLB tersebut, muncul sifat bangga bahwa dia mampu menjadi tenaga pengajar di tempat yang dulunya sebagai ladang pencarian ilmunya. Penilaian ketiga yaitu DLB merasa menjadi bagian keluarga besar UIN Sunan Ampel Surabaya. Hijrah dari tempat lama ke tempat baru menjadikan setiap insan yang memiliki pemikiran terbuka dan berimbas pada hati yang hangat. Kemudian, di tempat mana kita berpijak, pasti merasakan kekeluargaan, meskipun nantinya akan berpisah. Sama halnya dalam menjadi seorang DLB di setiap instansi. Lingkungan yang nyaman dengan setiap pelakunya yang selalu menjaga keharmonisan didalamnya menimbulkan rasa kekeluargaan anggota satu dengan yang lainnya.

Penilaian ke empat yaitu DLB menceritakan dan memberitahukan kepada masyarakat jika dia mengabdi di kampus tempat bekerja. Melalui penilaian ini, sangat membawa dampak positif bagi kampus dikarenakan hanya melalui mouth by the mouth mampu memasarkan kampus ataupun intansi kepada khalayak umum. Sehingga, khalayak umum atau publik berpikiran bahwa kampus atau intansi tersebut memang berbobot dikarenakan mahasiswa yang dulunya belajar di kampus tersebut menjadi DLB yang kompetitif dan kooperatif. Penilaian ke lima yaitu DLB perna merasakan sulit untuk meninggalkan kampus namun sangat menginginkannya. Terdapat karakter DLB yang berbeda sehingga tanggapannya pun juga berbeda. Salah satu alasan ketidak tegaan DLB meninggalkan kampus yaitu para mahasiswa. DLB tersebut merasa kasihan dikarenakan para mahasiswa sudah mengeluarkan biaya UKT yang cukup besar. Penilaian ke enam yaitu instansi merasa jika masalah yang dirasakan oleh DLB merupakan masalah mereka juga. Dalam penilaian ini, sebenarnya DLB tidak berpengaruh siginifikan terhadap komitmen instansi, namun dapat menjadi saran yang mendukung untuk perkembangan instansi selanjutnya. Penilaian ke tujuh yaitu DLB bertahan untuk tidak resigned sekalipun terdapat kebijakan yang tidak mengenakkan dan tidak menguntungkan. Komitmen dalam penilaian ini sangat kompleks dikarenakan setiap DLB memiliki pertimbangan yang berbeda dan pengambilan keputusan yang tak selaras.

\section{KESIMPULAN}

Berdasarkan dengan latar belakang, rumusan masalah, tujuan studi, tinjauan pustaka, metode penelitian serta hasil data dan pembahasan maka disusunlah kesimpulan. Kesimpulan ini disusun mengikuti pertanyaan dan pernyataan yang telah ditetapkan pada rumusan masalah. Kesimpulan studi ini adalah:

a. Tingkat profesionalisme Dosen Luar Biasa (DLB) di unit kerja seluruh Fakultas UIN Sunan Ampel Surabaya memiliki tingkat yang maksimal atau tinggi. Hal tersebut terbukti dari hasil wawancara mendalam dengan lima belas orang DLB yang tersebar dari enam fakultas yang terletak di UIN Sunan Ampel Surabaya. Penilaian tersebut terdiri dari level profesionalisme di atas 75 persen bagi 14 orang DLB sedangkan 1 orang memiliki profesioalisme sebesar 50 persen. Mengingat pendekatan penelitian yang digunakan adalah pendekatan kualitatif dan studi analisis konten. Maka hasil studi ini berbeda dengan penilaian kuantitatif, yang bisa saja menilai profesionalisme harus diukur dengan menilai responden dengan jumlah batas minimal yang sehingga nantinya didapatkan hasil yang representatif.

b. Implikasi adanya profesionalisme dari DLB kepada lingkungan kerja disekitar mereka tentunya diharapkan memberi dampak yang positif, juga meluas. Setidaknya hal seperti peningkatan kualitas mengajar akan berdampak lurus dengan prestasi mahasiswa, sikap dan perilaku mahasiswa, dan juga adab komunikasi para mahasiswa. Kemudian ketika 
profesionalisme DLB semakin meningkat maka dapat diamati bahwa kecenderungan sikap dan komitmen mengajar DLB akan semakin optimal pula.

Selain kesimpulan yang diberikan, perlu pula diberikan saran yang diberikan kepada beberapa pemangku kepentingan yang bersifat konstruktif, sebagaimana ulasan berikut:

a. Dosen Luar Biasa (DLB)

DLB selain mempertahankan kinerja dan komitmen kepada lembaga, DLB juga terus melakukan koreksi atas performance dari institusi dalam pemenuhan hak dan kewajiban mereka. Sehingga akan diperoleh proses check and balance yang juga mutualisme bagi kedua belah pihak.

b. Institusi terkait

DLB memang bukan bagian institusi yang konsisten mengajar dan berkantor rutin secara periodik, namun mereka harus diperhartikan pula komitmen, semangat, dan kesejahteraannya. Hal yang menjadi prioritasnya adalah setelah mereka menunaikan kewajibannya, maka sudah seharusnya institusi sesegera mungkin memberikan haknya, terlebih untuk kebutuhan fisiologis yang merupakan kebutuhan dasar yang wajib dipenuhi.

c. Mahasiswa atau Peneliti

Mahasiswa dan Peneliti dapat melajutkan penelitian ini pada objek studi yang berbeda dan skup yang berbeda pula, sehingga akan terus menambah khasanah keilmuan ekonomi serta ilmu manajemen sumber daya manusia dalam perspektif Islam.

\section{DAFTAR PUSTAKA}

Abul Hassan, Abdelkader Chachi and Salma Abdul Latiff, 2008, "Islamic Marketing Ethics and Its Impact on Customer Satisfaction in the Islamic Banking Industry", JKAU: Islamic Econ., Vol. 21 No. 1, pp: 27-46 (2008 A.D./1429 A.H.)

Ahmad, Khaliq dan Rodrigue Fontaine, 2011, "Islamic Leadership At The International Islamic University Malaysia", International Journal of Economics, Management and Accounting 19, no. 2: 124-135.

Anindia K,. Dilla. 2017. Analisis Pengaruh Profesionalisme Birokrasi terhadap Kinerja Pegawai pada Sekretariat Dinas Pariwisata dan Kebudayaan Provinsi Jawa Barat. Jurnal dipublikasikan Program Magister Ilmu Administrasi Program Pascasarjana Universitas Pasundan Bandung

Angga, P. S., Kusdi, R., M. Djudi, 2014, "Pengaruh Kompensasi Finansial Terhadap Kinerja (Studi pada Karyawan PT. Bank Jatim Cabang Malang)", Jurnal Administrasi Bisnis (JAB) Vol. 7 No. 2

Anggia D., Tiara. 2015. Pengaruh Profesionalisme Guru dan Motivasi Kerja terhadap Kinerja Guru Ekonomi SMA se-Kota Malang. Jurnal Promosi (Jurnal Pendidikan Ekonomi UM Metro) ISSN: 2442-9449. Vol.3 No.1.

Asry, M. Yusuf, 2008, "Pemahaman Keagamaan dan Etos Kerja Ekonomi dalam Masyarakat Islam di Kabupaten Bantul Yogyakarta", Jurnal Multikultural \& Multireligius, Vol. VII, No. 28, Oktober-Desember 2008.

Bungin, Burhan. 2003. Analisis Data Penelitian Kualitatif. Jakarta: Raja Grafindo Persada. Danny, H. I., Djamhur, H., Muhammad, F. R., 2014, "Pengaruh Kompensasi Finansial dan Non Finansial Terhadap Kinerja (Studi pada Agen AJB Bumiputera 1912 Kantor Cabang Blitar), Jurnal Administrasi Bisnis (JAB) Vol. 13 No. 1

Haywood-Farmer, J., \& Ian Stuart, F. 1990.An instrument to measure the 'degree of professionalism' in a professional service.Service Industries Journal, 10(2), 336-347. 
Herdiansyah, Haris. 2010. Metodologi Penelitian Kualitatif Untuk Ilmu-Ilmu Sosial. Jakarta: Salemba Humanika.

Hwang, H., and D. F Suárez. 2005. "Lost and found in the translation of strategic plans and Websites." In B. Czarniawska and G. Sevón (eds.), Global Ideas: How Ideas, Objects and Practices Travel in the Global Economy: 71-93. Malmo, Sweden: Liber AG.

Hwang, H., \& Powell, W. W. 2009. The rationalization of charity: The influences of professionalism in the nonprofit sector. Administrative Science Quarterly, 54(2), 268298.

Institut Manajemen Zakat. 2006. Profil 7 Badan Amil Zakat Daerah Provinsi dan Kabupaten Potensial di Indonesia. (Ciputat: PT Mitra Cahaya Utama,)

Kementerian Agama RI Direktorat Jenderal Bimbingan Masyarakat Islam Direktorat Pemberdayaan Zakat, 2015 Panduan Pengembangan Usaha Bagi Mustahik. (Jakarta: Kemenag RI)

Mamik, E. S., Umar, N., Hamidah, N. U., "Pengaruh Pelatihan, Kompensasi Terhadap Kepuasan Kerja Karyawan dan Kinerja Karyawan”, Jurnal Profit Vol. 6 No. 1, 25-37.

Nadjib, Muhammad, 2006, Etika Kerja dalam Ajaran dan Pandangan Masyarakat Islam, Jakarta: LIPI.

Nasurdin, Aizzat Mohd., Mohamad Abdullah Hemdi and Lye Phei Guat, 2008, "Does Perceived Organizational Support Mediate The Relationship Between Human Resource Management Practices And Organizational Commitment?", Asian Academy of Management Journal, Vol. 13, No. 1, 15-36, January 2008.

Novliadi, Ferry, 2008, Hubungan antara Organization-Based Self-Esteem dengan Etos Kerja, USU e-Repository

Prasetyo, Ari. 2015. Pengaruh Kepemimpinan Islami dan Kompensasi Finansial terhadap Komitmen dan Etos Kerja Islami serta Kinerja Karyawan pada Unit Usaha di Pondok Pesantren Jawa Timur. Disertas tidak dipublikasikan. Sekolah Pascasarjana. Program Doktoral Ekonomi Islam. Universitas Airlangga Surabaya

Sabet, M. G., \& Klingner, D. (1993). Exploring the impact of professionalism on administrative innovation. Journal of Public Administration Research and Theory, 3(2), 252-266.

Scholl, R. W. 1981, "Differentiating organizational commitment from expectancy as a motivating force" Academy of Management Review, 6: 589-599.

Sidani, Yusuf M. and Jon Thomberry, 2009, "The Current Arab Work Ethic: Antecedents, Implications, and Potential Remedies", Journal of Business Ethics

Smith, S. R., and M. Lipsky. 1993. Nonprofits for Hire: The Welfare State in the Age of Contracting. Cambridge, MA: Harvard University Press.

Widiastuti, Tika, 2013, Pengaruh Kepatuhan Seorang Muslim Berzakat (Muzakki), Kinerja Lembaga Zakat di BAZ dan LAZ Terhadap Kesejahteraan Mustahiq. Surabaya: Program Pasca Sarjana Universitas Airlangga. Disertasi tidak dipublikasikan

Yin, Robert K. L;2000. Studi Kasus: Desain dan Metode. Jakarta: PT. Raja Grafindo Wawancara dengan para Dosen Luar Biasa di Fakultas Ekonomi dan Bisnis Islam, Fakultas

Ilmu Sosial Ilmu Politik, Fakultas Sains dan Tekonologi, Fakultas Adab dan Humaniora, Fakultas Syariah dan Hukum, serta Fakultas Tarbiyah dan Keguruan 